\title{
THE EFFECT OF LEAD (Pb) LEVELS IN THE BLOOD ON HEMOGLOBIN (Hb) LEVELS IN BOOK PRINTING PERSONNEL ON JALAN KARAH SURABAYA
}

\author{
Ursula Yesi Gusti Ayuputri' ${ }^{1}$, Soedjajadi Keman ${ }^{1}$ \\ ${ }^{1}$ Department of Environmental Health \\ Faculty of Public Health, Airlangga University, Surabaya, Indonesia \\ Address correspondence: Ursula Yesi \\ Email: ursulayesi5@gmail.com
}

\begin{abstract}
Lead $(\mathrm{Pb})$ is a metal used as raw material for color pigments in printing ink. Pb exposure caused by printing ink can cause an increase in $\mathrm{Pb}$ levels in the blood and a decrease in hemoglobin levels. This study aimed to analyze the effect of $\mathrm{Pb}$ levels of ink on $\mathrm{Pb}$ levels in blood, as well as the effect of $\mathrm{Pb}$ levels in the blood on hemoglobin levels in book printing employees on Jalan Karah Surabaya. This study included analytic observational research, the research design used was the cross-sectional design, and the multiple linear correlation test was used for analysis. The results showed that the $\mathrm{Pb}$ level in ink had an effect on the $\mathrm{Pb}$ level in the blood $(\mathrm{p}=0.000 ; \mathrm{OR}=$ 0.762). The employee characteristics, namely work period, had an effect on $\mathrm{Pb}$ level in blood $(\mathrm{p}=0.000 ; \mathrm{OR}=$ 0.883). Age, use of Personal Protective Equipment (PPE) and personal hygiene do not affect the Pb level in the blood. $\mathrm{Pb}$ levels in the blood affect blood hemoglobin levels $(\mathrm{p}=0.001 ; \mathrm{OR}=-0.724)$. Employee characteristics, namely their work period, affect blood hemoglobin levels $(\mathrm{p}=0.046$; OR $=-0.4471)$. Age and nutritional status did not affect the blood hemoglobin level. The conclusion in this study is that Pb levels in ink increases Pb levels in the blood, and $\mathrm{Pb}$ levels in the blood decrease blood hemoglobin levels. Therefore, it is necessary to monitor lead levels in the blood by periodic examination every 6 or 12 months. Book printing personnel should also take supplements containing calcium, iron (Fe), and vitamin $\mathrm{C}$ to inhibit lead absorption.
\end{abstract}

Keywords: $\mathrm{Pb}$ levels in ink, blood $\mathrm{Pb}$ levels, $\mathrm{Hb}$ levels, printing employees.

\begin{abstract}
ABSTRAK
Timbal $(\mathrm{Pb})$ merupakan logam yang digunakan sebagai bahan baku pigmen warna pada tinta cetak. Pajanan Pb yang disebabkan karena tinta cetak dapat menyebabkan peningkatan kadar Pb dalam darah dan penurunan kadar hemoglobin. Penelitian ini bertujuan untuk menganalisis pengaruh kadar Pb pada tinta terhadap kadar $\mathrm{Pb}$ dalam darah dan kadar $\mathrm{Pb}$ dalam darah terhadap kadar hemoglobin pada pegawai percetakan buku di Jalan Karah Surabaya. Penelitian ini termasuk penelitian observasional yang bersifat analitik, desain penelitian yang digunakan adalah desain cross sectional, dan analisis yang digunakan adalah uji korelasi linear berganda. Hasil penelitian menunjukan bahwa kadar Pb pada tinta berpengaruh terhadap kadar Pb dalam darah $(\mathrm{p}=$ 0,000; $\mathrm{OR}=0,762)$, karakteristik pegawai yaitu masa kerja berpengaruh terhadap kadar Pb dalam darah $(\mathrm{p}=$ 0,000; OR = 0,883). Sedangkan usia, pemakaian Alat Pelindung Diri (APD) dan higiene perorangan tidak berpegaruh terhadap kadar $\mathrm{Pb}$ dalam darah. Kadar Pb dalam darah berpengaruh terhadap kadar hemoglobin darah $(\mathrm{p}=0,001 ; \mathrm{OR}=-0,724)$, karakteristik pegawai yaitu masa kerja berpengaruh terhadap kadar hemoglobin darah ( $\mathrm{p}=0,046 ; \mathrm{OR}=-0,471)$. Sedangkan usia dan status gizi tidak berpegaruh terhadap kadar hemoglobin darah. Kesimpulan dalam penelitian ini adalah kadar Pb pada tinta berpengaruh terhadap peningkatan kadar $\mathrm{Pb}$ dalam darah dan kadar $\mathrm{Pb}$ dalam darah berpengaruh terhadap penurunan kadar hemoglobin darah. Oleh karena itu, perlu dilakukan pemantauan kadar timbal dalam darah dengan cara pemeriksaan berkala setiap 6 bulan sekali atau 12 bulan sekali dan mengkonsumsi suplemen yang mengandung kalsium, Fe dan vitamin C guna menghambat penyerapan timbal.
\end{abstract}

Kata kunci: kadar Pb pada tinta, kadar Pb dalam darah, kadar Hb, pegawai percetakan.

\section{INTRODUCTION}

Heavy metals are toxic environmental pollutants and are of great concerns because they can have a negative impact on human health (Bangun, 2005).
There are various types of heavy metals, one of which is lead $(\mathrm{Pb})$. Lead is a major pollutant in the surrounding environment that can endanger human health because it can accumulate within the human body (Hasan et al., 2013). 
Lead $(\mathrm{Pb})$ is a natural element that was widely used in early human life, and many industries still use lead in their production activities today. This leads to environmental pollution caused by lead to become more widespread (CDC, 2011). According to the World Health Organization (WHO) (2010), living things can be exposed to lead through polluting media including children's toys, environmental air, $\mathrm{Pb}$ contained in drinking water from piped water, batteries, paint sets, colored pencils, makeup equipment, printing inks, unnecessary to include, household furniture, and soil. According to Darmono (2001), workers who work in mining, battery manufacturing, metal coating, vehicle painting, and printing can be chronically exposed to lead.

Printing is a technology whose production results are in the form of duplicates which are carried out as soon as possible, including sentences or portraits of things on the surface of paper, cloth, and other usable surfaces. Over time, more and more printed materials will be produced. In the production process, lead is utilized to improve the quality of printouts (Oke et al., 2008). According to the Indonesian Ministry of Industry (2018), the number of printing industries that were recorded in Indonesia in 2018 amounted to 317 . The printing companies located on Jalan Karah Surabaya were not included in the record.

According to EUPIA (2013), the ink in the printing process contains lead $(\mathrm{Pb})$. The printing industry utilizes an inorganic lead compound that has carcinogenic effects on humans (IARC, 2006). ATSDR (2007) states that the lead $(\mathrm{Pb})$ threshold value in ink is $90 \mathrm{ppm}$. Printing employees have a higher risk of lead exposure to their work (ACS, 2014). According to ATSDR (2007), lead (Pb) ranks second after arsenic the most toxic heavy metal in terms of its presence in the environment, its toxicity, and potential exposure to humans. According to Oke et al. (2008), printing employees who work without using personal protective equipment (PPE) in front of printing machines will be vulnerable to $\mathrm{Pb}$ exposure.

Lead can enter the body through air, food, drinks, and raw materials. Lead can also be absorbed by the body through respiration, digestion, and skin. The greater the $\mathrm{Pb}$ level in the environment, the greater the $\mathrm{Pb}$ level in the blood. According to Palar (2012), $95 \%$ of lead in the environment enters the human body and will be bound to blood. Lead that enters the blood is bound to erythrocytes, and 5\% is bound to blood plasma. The body can accumulate toxic lead compounds, and it can endanger human health if it remains in the body for a long duration of time.

The WHO (2010) set a blood lead threshold value of less than $10 \mu \mathrm{g} / \mathrm{dL}$. California Department of Public Health (CDPH) (2009) states that the level of lead in the blood describes the amount of lead that has stayed in the body. According to Palar (2012), Pb poisoning has several effects: 1) increased levels of amino levulinic acid (ALA) in blood and urine; 2) increased levels of protoporphirin in red blood cells; 3) shortened lifespan of red blood cells; 4) reduced number of red blood cells; 5) reduced levels of reticulocytes (young red blood cells).

According to Yartireh et al. (2013), decreased intelligence quotient, high blood pressure, central nervous system disorders, and the hematopoietic system are health impacts caused by blood lead levels exceeding the standard threshold value. According to the aforementioned study, the disruption of the hematopoietic system disturbs the formation of hemoglobin. If the hemoglobin formation process is disturbed, the number of erythrocytes in the blood will decrease and can cause anemia. According to the WHO (2005), the normal limit of $\mathrm{Hb}$ levels for men is $\geq 13$ $\mathrm{g} / \mathrm{dL}$. The prevalence of anemia in the world in 1993-2005 ranged from 40-88\% (WHO, 2008). The prevalence of anemia 
in Indonesia has been recorded as $21.7 \%$ (Riskesdas, 2013).

According to Al-Malki and Abdulrachman (2009), there is a change in the relationship between lead levels in the blood and hemoglobin levels. Research by Oke et al. (2008) showed a relationship between lead levels in the blood and a decrease in hemoglobin levels in printing workers in Nigeria. Research by Inswiasri and Sintawati (2016) showed that there was a significant relationship between $\mathrm{Pb}$ levels in the blood and blood $\mathrm{Hb}$ levels in children in the ulan cycle area of used batteries in Bogor, Bekasi, Tangerang and Depok. Research conducted by Mahendra (2016) showed that there was a significant relationship between lead levels in the blood and hemoglobin levels in book market traders in Sriwedari, Surakarta. According to him, blood hemoglobin levels are influenced by several factors including gender, age, and nutritional status.

Employees who work in the printing department are at risk of being exposed to the lead $(\mathrm{Pb})$ contained in the ink for printing. Therefore, the authors took the research title "The Effect of Lead $(\mathrm{Pb})$ Levels in Blood on Hemoglobin $(\mathrm{Hb})$ Levels in Book Printing Employees on Jalan Karah Surabaya".

\section{METHODS}

This study utilized observational method, which is analytic in nature. The research design used was a cross-sectional design. The population of this study was printing employees on Jalan Karah Surabaya. The sampling technique used in this study was the simple random sampling done by adhering to predetermined criteria, namely male employees who were willing to be interviewed and willing to have their blood drawn. The research samples were employees who worked in the administration section and employees who worked in the printing department. There was a total sample of 16 people obtained from the formula for the population mean hypothesis test. This research was conducted on March 18, 2019 at a book printing shop located on Jalan Karah Surabaya. The independent variables in this research were $\mathrm{Pb}$ levels in the ink, while the dependent variables were blood lead levels and $\mathrm{Hb}$ levels. Confounding variables included worker characteristics, namely working period, age, use of PPE, personal hygiene, and nutritional status. Lead $(\mathrm{Pb})$ levels in blood and in printing employees' ink were measured by means of laboratory tests using the atomic absorption spectrophotometry (AAS) method, while blood hemoglobin $(\mathrm{Hb})$ levels were measured using the hematology autoanalyzer method. Blood sampling was carried out by experts from the Conscience Clinic who were competent in taking blood specimens. The blood samples then went through testing in private laboratories.

This study used the multiple linear correlation test to analyze the levels of lead $(\mathrm{Pb})$ in the ink and the characteristics of the employees with varying levels of lead $(\mathrm{Pb})$ in their blood. It was also used to analyze the levels of lead $(\mathrm{Pb})$ in the blood and the characteristics of the employees with varying levels of blood hemoglobin $(\mathrm{Hb})$. This study has passed the ethical review from the Ethics Commission of the Faculty of Public Health, Universitas Airlangga, Surabaya Number 90/EA/KEPK/2019.

\section{RESULT}

\section{Levels of Lead in Ink}

ATSDR (2007) sets a threshold value for lead levels in ink of more than 90 ppm.

Table 1. Results of Measurement of $\mathrm{Pb}$ Levels in Printing Ink on Jalan Karah Surabaya in 2019

\begin{tabular}{cc}
\hline Variable & Value (ppm) \\
\hline $\mathrm{Pb}$ levels in the ink & 3,61 \\
\hline
\end{tabular}


The results showed that there was lead content in printing ink amounting to $3.61 \mathrm{ppm}$. The ink content did not exceed the threshold set by the ATSDR.

\section{Levels of Lead $(\mathrm{Pb})$ in Blood}

The WHO (2010) set a threshold value for $\mathrm{Pb}$ in blood of less than or equal to $10 \mu \mathrm{g} / \mathrm{dL}$.

Table 2. Distribution of $\mathrm{Pb}$ Levels in Blood of Printing Employees on Jalan Karah Surabaya in 2019

\begin{tabular}{ccccccc}
\hline \multirow{2}{*}{$\begin{array}{c}\text { Blood } \\
\text { lead } \\
\text { levels } \\
(\boldsymbol{\mu g g / d} \\
\mathbf{L})\end{array}$} & \multicolumn{4}{c}{ Exposed } & $\begin{array}{c}\text { Category } \\
\text { Exposed }\end{array}$ & \multirow{2}{*}{ Total } \\
\cline { 2 - 6 } & $\mathbf{n}$ & $\%$ & $\mathbf{n}$ & $\%$ & & \% \\
\hline$\leq 10$ & 3 & 18,8 & 8 & 50 & 11 & 68,8 \\
$>10$ & 5 & 31,2 & 0 & 0 & 5 & 31,2 \\
\hline Total & 8 & 50 & 8 & 50 & 16 & 100 \\
\hline
\end{tabular}

Table 2 shows that $31.2 \%$ of respondents had blood $\mathrm{Pb}$ levels of more than $10 \mu \mathrm{g} / \mathrm{dL}$ in the exposed group, and $18.8 \%$ of respondents had blood $\mathrm{Pb}$ of less than $10 \mu \mathrm{g} / \mathrm{dL}$. In the unexposed group, there were no respondents who had $\mathrm{Pb}$ levels in the blood of more than $10 \mu \mathrm{g} / \mathrm{dL}$, and $50 \%$ of respondents had $\mathrm{Pb}$ levels in the blood of less than $10 \mu \mathrm{g} / \mathrm{dL}$.

\section{Blood Hemoglobin Levels}

The WHO (2011) sets the normal standard for male hemoglobin levels to be more than or equal to $13 \mathrm{~g} / \mathrm{dL}$. Table 3 shows that $12.5 \%$ of respondents in the exposed group had blood $\mathrm{Hb}$ levels of less than $13 \mathrm{~g} / \mathrm{dL}$, and $37.5 \%$ of respondents had blood $\mathrm{Hb}$ levels greater than $13 \mathrm{~g} / \mathrm{dL}$. Whereas, in the unexposed group, there were no respondents who had $\mathrm{Hb}$ blood levels below $13 \mathrm{~g} / \mathrm{dL}$, and $50 \%$ of respondents had $\mathrm{Hb}$ levels greater than or equal to $13 \mathrm{~g} / \mathrm{dL}$.
Table 3. Distribution of $\mathrm{Hb}$ Blood Levels in Printing Employees on Jalan Karah Surabaya in 2019

\begin{tabular}{ccccccc}
\hline \multirow{2}{*}{$\begin{array}{c}\text { Hb } \\
\text { levels } \\
\text { (g/dL }\end{array}$} & \multicolumn{4}{c}{ Category } & \multicolumn{2}{c}{ Total } \\
\cline { 2 - 5 } ) & $\mathbf{n}$ & $\mathbf{\%}$ & $\mathbf{n}$ & $\boldsymbol{\%}$ & $\mathbf{n}$ & $\boldsymbol{\%}$ \\
\hline$<13$ & 2 & 12,5 & 0 & 0 & 2 & 12,5 \\
$\geq 13$ & 6 & 37,5 & 8 & 50 & 14 & 87,5 \\
\hline Total & 8 & 50 & 8 & 50 & 16 & 100 \\
\hline
\end{tabular}

Effect of lead levels (Pb) on ink and employee characteristics on levels of lead $(\mathrm{Pb})$ in blood

Table 4. Analysis of the Effect of Lead $(\mathrm{Pb})$ Levels of Ink and Employee Characteristics on Levels of Lead $(\mathrm{Pb})$ in the Blood of Printing Employees on Jalan Karah Surabaya in 2019

\begin{tabular}{ccc}
\hline \multirow{2}{*}{ Variable } & \multicolumn{2}{c}{ Blood lead levels } \\
\cline { 2 - 3 } & $\mathbf{R}$ & $\mathbf{p}$ \\
\hline Pb levels of ink & 0,762 & $0,000^{* *}$ \\
Years of service & 0,883 & $0,000^{* *}$ \\
Age & 0,126 & 0,667 \\
PPE & 0,126 & 0,641 \\
Personal Hygiene & 0,368 & 0,161 \\
\hline${ }^{*} p<0,05$ (signifikan) & \multicolumn{2}{c}{}
\end{tabular}

The analysis results of the effect of lead levels in ink and employee characteristics on blood lead levels proved that lead levels in ink affected blood lead levels ( $\mathrm{p}=0.000$; OR =0.762). OR shows a positive relationship or a unidirectional relationship, which means that lead content in the ink will increase the lead in the blood. There is also an effect of tenure on blood lead levels ( $p=0.000$; OR $=0.883$ ). OR shows a positive relationship or a unidirectional relationship, which means that the longer the employee works, the larger the increase of lead in their blood. While the age variable, PPE and personal hygiene had no effect on the blood lead $(\mathrm{Pb})$ level $(\mathrm{p}=0.667 ; \mathrm{OR}=0.126)$. The PPE variable had a $p$-value of 0.641 and an OR of 0.126 . Individual hygiene variables 
had a p-value of 0.161 and an OR of 0.368 .

\section{Effect of lead $(\mathrm{Pb})$ levels in blood and employee characteristics on blood hemoglobin $(\mathrm{Hb})$ levels}

The results of the analysis of the effect of lead $(\mathrm{Pb})$ levels in blood and employee characteristics on hemoglobin $(\mathrm{Hb})$ levels showed that there was an effect of $\mathrm{Pb}$ levels in the blood on blood $\mathrm{Hb}$ levels with a p-value of 0.001 and an OR of -0.724. $\mathrm{R}$ indicates a negative relationship or a relationship in the opposite direction, which means that if the higher the lead level in the blood, the blood $\mathrm{Hb}$ level will decrease. There was an effect of tenure on blood $\mathrm{Hb}$ levels with a p-value of 0.046 and an OR of -0.471 . OR shows a negative relationship or a relationship in the opposite direction, which means that the longer the employee works, the blood $\mathrm{Hb}$ level will decrease. While the variable age $(\mathrm{p}=0.901)$ and nutritional status $(\mathrm{p}=0.691)$ did not affect blood $\mathrm{Hb}$ levels.

Table 5. Analysis of the Effect of Lead $(\mathrm{Pb})$ Levels and Employee Characteristics in Blood on Hemoglobin $(\mathrm{Hb})$ Levels of Printing Employees on Jalan Karah Surabaya in 2019

\begin{tabular}{ccc}
\hline \multirow{2}{*}{ Variable } & \multicolumn{2}{c}{ Kadar Hb Darah } \\
\cline { 2 - 3 } & $\mathbf{R}$ & $\mathbf{p}$ \\
\hline Blood lead levels & $-0,724$ & $0,001^{* *}$ \\
Years of service & $-0,471$ & $0,046^{*}$ \\
Age & $-0,258$ & 0,901 \\
Nutritional status & 0,226 & 0,691 \\
\hline
\end{tabular}

$* p<0,05$ (signifikan)

\section{DISCUSSION}

\section{Effect of lead $(\mathrm{Pb})$ levels on ink and employee characteristics on levels of lead $(\mathbf{P b})$ in blood}

Lead can be absorbed by the body through air, food, drinks, and raw materials. Furthermore, lead can also be absorbed by the body through breathing, digestion, and penetration of the skin layer. Once absorbed it will then be transported throughout the body by blood. According to Palar (2012), 95\% of lead in the environment enters the human body and binds to blood. Lead that enters the blood is bound to erythrocytes, and $5 \%$ is bound to blood plasma. According to Hasal et al. (2013), the human body can absorb lead in small volumes, but the toxic effect is damaging for all kinds of organ functions. Palar (2012) states that $0.06 \%$ of inorganic lead is absorbed through the skin. Lead which is absorbed can have carcinogenic effects in humans.

There were 16 male employees who had their blood drawn and examined. Examination of $\mathrm{Pb}$ levels in the blood is the best indicator to show current exposure, and this applies to workers who are exposed to lead continuously. The standard or threshold value for lead levels in the blood set by the WHO (2010) is <10 $\mu \mathrm{g} / \mathrm{dL}$.

The results of multiple linear correlation analysis prove that there is an effect of $\mathrm{Pb}$ levels in the ink on $\mathrm{Pb}$ levels in the blood with a p-value of 0.000 and an OR of 0.762 . OR shows a positive or unidirectional relationship, which means that $\mathrm{Pb}$ content in the ink will increase $\mathrm{Pb}$ levels in the blood.

The lead content in printing ink was $3.61 \mathrm{ppm}$. ATSDR (2007) states that the threshold value for lead $(\mathrm{Pb})$ in ink is $90 \mathrm{ppm}$. Even though the ink did not exceed the threshold value, this must still be considered because lead can accumulate within the human body (Hasan et al., 2013). In addition, 5 out of 16 respondents had that exceeded $10 \mu \mathrm{g} / \mathrm{dL}$. Lead exposure to printing employees occurred during the printing press operation and due to holding printing ink without PPE in the form of gloves, meaning the skin was in direct contact with the printing ink. work. The results of these examinations prove that the $\mathrm{Pb}$ content in the ink can increase 
the $\mathrm{Pb}$ in the blood. Research conducted by Al-Hassani and Ansam (2013) showed that there was a significant increase in blood lead levels in printing workers in Iraq.

Other factors that can affect the $\mathrm{Pb}$ levels in blood are the employees' working period, nutritional status, use of PPE, personal hygiene, and age. According to Patrick (2006), lead exposure in the environment can interfere with one's health, due to the buildup of $\mathrm{Pb}$ in the body that cannot be excreted. The length of time a person works will contribute to the amount of lead that enters their body.

The multiple linear correlation analysis showed that there is an effect of tenure on $\mathrm{Pb}$ levels in the blood $(\mathrm{p}=0.000$; OR $=0.883)$. OR shows a positive or unidirectional relationship, which means that the longer the employee works, the more lead in their blood. According to Sutomo (2003), when a person works in an environment where there is exposure to chemicals or heavy metals, it describes the exposure found in the environment. The length of time people work will affect their exposure to heavy metal pollutants.

A similar study was conducted by Dewi (2016) that showed the effect of tenure on increasing blood lead levels with a p-value of 0.014. Maksum (2013) states that length of work affects blood lead levels at gasoline retailers, and the length of service life of gasoline retailers will increase blood lead levels. According to Rustanti and Mahawati (2011), tenure has a significant relationship with blood lead levels. Similar research was also conducted by Eka (2016) that stated tenure has a strong relationship with blood lead levels. Meanwhile, the age variable had no effect on $\mathrm{Pb}$ levels in the blood which had a $\mathrm{p}$ value of 0.667 .

Other factors that affect the level of lead in the blood are the use of PPE and personal hygiene. The analysis results on the use of PPE had a p-value of 0.126 and the results on personal hygiene had a $\mathrm{p}$ value of 0.161 . This indicated a $p$-value of more than 0.05 , therefore it can be said that the variables of age, use of PPE, personal hygiene, and nutritional status have no effect on $\mathrm{Pb}$ levels in blood. The research results are in line with research by Aini (2016), which stated that age and the use of PPE do not have a strong relationship with blood lead levels in printing employees. A study conducted by Firdaust (2016) on lead smelting workers found the age variable had no effect on the level of lead in the blood with a p-value of 0.301 . Similar research was also conducted by Mahendra (2016) that indicated the variable of age and blood lead levels did not have a significant relationship.

\section{Effect of lead $(\mathrm{Pb})$ levels in blood and employee characteristics on blood hemoglobin (Hb) levels}

According to Yartireh et al. (2013), decreased intelligence quotient, high blood pressure, central nervous system disorders, and the hematopoietic system are health impacts caused by blood lead levels exceeding the standard threshold value. According to him, the disruption of the hematopoietic system is a disturbance during the formation of hemoglobin. If the process of hemoglobin formation is disturbed, the number of erythrocytes in the blood will decrease, which can cause anemia. Hemoglobin is an important element in erythrocytes, and has a role in the transportation of oxygen from the lungs to body tissues (Guyton and Hall, 2014). Hemoglobin levels can decrease because of the lead content in the blood (Yartireh et al., 2013).

The multiple linear correlation analysis showed that $\mathrm{Pb}$ levels in the blood affected blood $\mathrm{Hb}$ levels $(\mathrm{p}=0.001$; OR $=$ -0.724). OR shows a negative relationship or relationship in the opposite direction, which means that the higher the lead level in the blood, the lower the blood $\mathrm{Hb}$ level. A similar study conducted by Firdaust (2016) stated that the influence of $\mathrm{Pb}$ levels in the $\mathrm{Hb}$ levels with a p-value of 0.000 had a negative relationship, meaning that an increase in $\mathrm{Pb}$ levels in the blood 
would reduce blood $\mathrm{Hb}$ levels. Oke et al. (2008) showed that there was a significant relationship between blood lead levels and decreases in hemoglobin levels among printing workers. Research conducted by Inswiasri and Sintawati (2016) showed that the $\mathrm{Pb}$ levels in the blood had a significant relationship with the blood $\mathrm{Hb}$ levels in Bogor, Bekasi, Tangerang, and Depok. Research by Mahendra (2016) showed that there is a significant relationship between lead levels in the blood and hemoglobin levels among book traders in the Surakarta book market. According to Suhendro et al. (2007), blood lead levels of city bus drivers in Surabaya were more than or equal to $10 \mu \mathrm{g} / \mathrm{dL}$. Their blood lead levels strongly correlated with anemia symptoms and a decrease in $\mathrm{Hb}$ levels. A similar study was also conducted by Al-Malki and Abdulrachman (2009) which found a strong relationship between lead levels in the blood and hemoglobin levels.

Lead levels in the blood have a role of $12 \%$ in reducing hemoglobin levels. Disorders of the hematopoietic system due to lead exposure can occur due to suppression of hemoglobin $(\mathrm{Hb})$ synthesis. This can happen through inhibition of the release of the ALAD enzyme, which is one of the stages of heme and erythrocyte synthesis. The presence of lead in the blood will disrupt the working system of the enzyme, causing disruption of the erythrocyte synthesis process. Therefore, anemia can occur (Assi, 2016).

Additional factors that affect blood hemoglobin levels are years of service, nutritional status, and age. The multiple linear correlation analysis proved the effect of tenure on blood $\mathrm{Hb}$ levels ( $\mathrm{p}=0.046$; OR $=-0.471)$. OR shows a negative relationship or a relationship in the opposite direction, which means that the longer the employee works, the lower the blood $\mathrm{Hb}$ level. A similar study conducted by Sumiati (2006) showed that there was a significant relationship between tenure and blood hemoglobin levels. The p-value of 0.016 was obtained from the results of the correlation of Pearson's product moment for workers in the braking of two small leather shoe industries in Semarang. The length of time someone works will affect the amount of $\mathrm{Pb}$ that enters the body (Patrick, 2006). Disruption of the hematopoietic system causes disruption to the process of hemoglobin formation, and workers in places with $\mathrm{Pb}$ exposure will tend to suffer from this disorder.

The results of multiple linear correlation analysis showed the variable of age had a p-value of 0.901, while nutritional status had a p-value of 0.691 . Therefore, it can be said that the variables of age and nutritional status have no effect on reducing blood hemoglobin levels. Research conducted by Mahendana (2016) also found that the variables of age and nutritional status had a $p$-value of more than 0.05 , indicating that there was no relationship between age and nutritional status with $\mathrm{Hb}$ levels. Similar research conducted by Ronayan (2015) stated that there was no significant relationship between age and blood hemoglobin levels. Sjarifah et al. (2015) showed that the characteristics of respondents including gender, smoking habits, and nutritional status had no effect on reducing blood hemoglobin levels.

According to Patel (2008), blood hemoglobin levels will increase or even decrease along with the stages of human life. Blood hemoglobin levels can decrease due to iron and vitamin B12 deficiencies. This can also be caused by genetic factors where abnormal hemoglobin molecules are found, which results in low oxygen concentrations in the body (Sloane, 2013).

\section{CONCLUSION}

Lead levels in ink had an effect on the increase in blood lead levels ( $\mathrm{p}=$ $0.000 ; \mathrm{OR}=0.762$ ). The characteristics of employees, namely tenure, have an effect on the increase in lead levels in the blood $(p=0.000 ;$ OR = 0.883). Meanwhile, age, the use of PPE, and personal hygiene did 
not affect the blood lead levels of the book printing staff on Jalan Karah Surabaya. Blood lead levels had an effect on reducing blood hemoglobin levels $(\mathrm{p}=0.001$; OR $=$ -0.724). Employee characteristics, namely tenure, had an effect on reducing blood hemoglobin levels $(\mathrm{p}=0.046$; OR $=$ 0.471). Age and nutritional status did not affect the blood hemoglobin level of the book printing staff on Jalan Karah Surabaya.

Employees and companies are advised to monitor blood lead levels every 6 or 12 months for employees who work in printing shops located on Jalan Karah Surabaya, especially those who work in the printing department. They are also advised to improve personal hygiene by washing hands with soap after direct contact with ink, showering after work, and changing dirty clothes with clean ones. They should also use personal protective equipment in the form of masks and gloves at work to minimize lead exposure in the body. Finally, they should consume foods or supplements containing calcium, iron, and vitamin $\mathrm{C}$ to inhibit lead absorption in the blood.

\section{REFERENCE}

ACS. 2014. Lead. America Cancer Society.

Aini, R. 2016. Analisis Kadar Logam Berat Timbal $(\mathrm{Pb})$ dalam Darah dan Keluhan Kesehatan Pegawai Percetakan di Pusat Penerbitan dan Percetakan Buku Universitas Airlangga. Skripsi. Universitas Airlangga Surabaya: Surabaya.

Al-Hassani., and Ansam, N. 2013. Survey Study og Lead Exposure among Lead Workers in Erbil. Iraq $J$ Pharm, 13(1):51-57.

Al-Malki., and Abdulrachman, L. 2009. Serum Heavy Metals and Hemoglobin Related Compounds in Saudi Arabia Firefighters. Journal Occupational Medicine and Toxicology. 4(18):1-8. https://doi.org/10.1186/1745-66734-18

Assi, M. 2016. The detrimental effects of lead on human and animal health. Veterinary World EISSN: 22310916.

https://doi.org/10.14202/vetworld.2 $\underline{016.660-671}$

ATSDR. 2007. Consumer Product Safety Commition. Agency For Toxic Substances And Disease Registry. USA.

ATSDR. 2007. Substance Priority List. Buford Hwy NE Atlanta.

Bangun, J. 2005. Kandungan Logam Berat Timbal $(\mathrm{Pb})$ dan Kadmium $(\mathrm{Cd})$ dalam Air, sedimen dan organ tubuh ikan sokang (Triacanthus nichofi) di perairan Ancol, Teluk. Fakultas perikanan dan Ilmu Kelautan. Skripsi. Institut Pertanian Bogor : Jakarta.

CDC. 2011. NIOSH Safety and Health Topic: Adult Blood Lead Epidemiology and Surveillance (ABLES). Centers for Disease Control and Prevention.

CDPH. 2009. Medical Guideline for Teh Lead exposed Worker. California Departement Of Public Health.

Darmono. 2001. Lingkungan hidup dan pencemaran hubungannya dengan toksikologi senyawa logam. Penerbit Universitas Indonesia : Jakarta

Dewi, U. 2016. Pengaruh Masa Kerja Dan Penggunaan Masker Terhadap Kadar Timbal $(\mathrm{Pb})$ Darah Petugas Parkir Akibat Paparan Gas Buang Kendaraan Di Wilayah Pasar Kecamatan Ngabang Kalimantan Barat. Skripsi. Universitas Kristem Maranatha Bandung: Bandung

Eka, H. 2016. Hubungan Kadar Timbal dalam Ruang dan dalam Darah dengan Hipertensi dan Keluhan Kesehatan pada Pekerja Bengkel Pengecatan Mobil di Surabaya. Skripsi. Universitas Airlangga Surabaya: Surabaya. 
EUPIA. 2013. Evirontment Impact of Printing Inks. Europian Printing Ascociation.

Firdaust, M. 2015. Pengaruh Pajanan Pb di Udara Terhadap Kadar $\mathrm{Pb}$ Darah, $\mathrm{Hb}$, Eritrosit, Gamma-GT, Cystatin C Serum dal Keluhan Kesehatan Pekerja Peleburan Timah Hitam di Kabupaten Tegal. Skripsi. Universitas Airlangga Surabaya: Surabaya.

Guyton and Hall. 2014. Buku Ajar Fisiologi Kedokteran. Edisi keduabelas

Hasan, R., Alvi, S., and Chatarina, U. 2013. Pengaruh jenis kelamin dan kebiasaan merokok terhadap kadar timbal darah. Jurnal kesehatan masyarakat, $\quad 8(4): 164-168$. https://doi.org/10.21109/kesmas.v0 i0.391

IARC. 2009. Monographs on the Evaluation of Carcinogenic Risks to Humans. World Health Organization.

Inswiasri and Sintawati. 2016. Hubungan Kadar $\mathrm{Pb}$ Dengan Kadar $\mathrm{Hb}$ Pada Anak Di Wilayah Daur Ulang Aki Bekas Informal Di Bogor, Depok, Tangerang, Dan Bekasi. Jurnal Ekologi Kesehatan, 15(2):87-96. https://doi.org/10.22435/jek.v15i2. $\underline{4788.87-96}$

Indonesian Ministry of Industry. 2019. Direktori Perusahan Industri Jenis Komoditi Percetakan. Jakarta.

Mahendra, O. 2016. Hubungan kadar timbal dalam darah denga kadar hemoglobin pada pedagang pasar buku belakang Sriwedari Surakarta. Naskah Publikasi. Universitas Sebelas Maret Surakarta: Surakarta.

Maksum, T. 2013 Studi Keterpaparan Timbal $(\mathrm{Pb})$ pada Penjual Bensin Eceran di Wilayah Kecamatan Dungingi Kota Gorontalo. Skripsi. Universitas Negeri Gorontalo.

Oke, S., Philips, T., Kolawole., Ofiabulu and Adeyeye, S. 2008. occupational lead exposure in printing process an analytical approach. The Pacific Journal of Science and Technology, 9(1).

Palar, H. 2012. Pencemaran dan Toksikologi Logam Berat. Jakarta: Rineka Cipta

Patel, K. 2008. Variability and Heritability of Hemoglobin Concentration: An Opportunity to Improve Understanding of Anemia in Older Adults. Haematologic. 93(9):12811283.

https://doi.org/10.3324/haematol.13 $\underline{692}$

Patrick, L. 2006. Lead Toxicity, A Review of the literature. Alternative medicine review, 11 (1).

Riskesdas. 2013. Laporan Hasil Riset Kesehatan Dasar (RISKESDAS) 2013. Jakarta : Kementerian Kesehatan RI

Ronayan, B. 2015. Hubungan Karakteristik Individu Terhadap Kadar Timbal dalam Darah dan Dampaknya pada Kadar Hemoglobin Pekerja Percetakan di Kawasan Megamall Ciputat Tahun 2015. Skripsi. Universitas Islam Negeri Syarif Hidayatullah Jakarta: Jakarta.

Rustanti, I., and Mahawati, E. 2011. Faktor-faktor yang Berhubungan dengan Kadar Timbal $(\mathrm{Pb})$ dalam Darah Pada Sopir Angkutan Umum Jurusan Karang Ayu Panggaron di Kota Semarang. Jurnal Visikes, 10(1).

Sjarifah, I., Khotijah., and Setiawan. 2015. Hubungan Kadar Timah Hitam $\mathrm{Pb}$ dengan kadar Hemoglobin (Hb) dan Tekanan Darah pada Pekerja SPBU di Kerasidenan Surakarta. The Indonesian Publication Index. Universitas Muhammadiyah Purwokerto.

Sloane, E. 2003. Anatomi dan Fisiologi Untuk Pemula. Jakarta: Penerbit Buku Kedokteran EGC.

Suhendro., Soedibyo, $\mathrm{H}$ and Windhu, P. 2007. Kandungan Timbal Dalam Darah dan Dampak Kesehatan Pada 
Pengemudi Bus Kota AC dan Non AC di Kota Surabaya. Jurnal Kesehatan Lingkungan, 3(2):127136.

Sumiati, Y. 2006. Hubungan Masa Kerja Dengan Kadar Hemoglobin Darah Pada Pekerja Bagian Pengeman Dua Industri Kecil Sepatu Kulit Di Semarang. Skripsi. Universitas Diponegoro: Semarang.

Sutomo, A. 2003. Pengaruh lama kerja terhadap kontaminasi timbal di kalangan pekerja pengelola uang di Yogyakarta. Laporan Penelitian. Universitas Gajahmada; Yogyakarta.

WHO. 2005. Haemoglobin Concentrations For The Diagnosis Of Anemia And Assessment Of Severity. Vitamin and Mineral Nutrition Information System

WHO. 2008. Worldwide prevalence of anaemia 1993-2005: WHO global database on anaemia. Geneva, Switzerland: World Health Organization.

WHO. 2010. Exposure to lead. A major public health concern. Preventing disease through healthy environments. Public health and environment.

Yartireh., Haji, A., and Amir, H. 2013. The effect of Occupational Exposure to Lead on Blood Hemoglobin Concentration in Worker of Karmashah Oil Refinery. Iranian Journal of Toxicology, 6(19):766770. 